\title{
Faktor-Faktor yang Berhubungan dengan Status Gizi Anak Balita di Wilayah Kerja Puskesmas Nanggalo Padang
}

\author{
Rona Firmana Putri ${ }^{1}$, Delmi Sulastri ${ }^{2}$, Yuniar Lestari $^{3}$
}

\section{Abstrak}

Status gizi anak balita salah satunya dipengaruhi oleh faktor kondisi sosial ekonomi, antara lain pendidikan ibu, pekerjaan ibu, jumlah anak, pengetahuan dan pola asuh ibu serta kondisi ekonomi orang tua secara keseluruhan. Penelitian ini dilakukan untuk mengetahui apakah ada hubungan kondisi sosial ekonomi keluarga terhadap status gizi anak balita. Penelitian ini adalah survei analitik menggunakan desain cross sectional study dengan jumlah sampel 227 orang yang terdiri dari anak balita dan ibu balita di Wilayah Kerja Puskesmas Nanggalo Padang. Data dikumpulkan melalui kuesioner yang telah diisi oleh ibu balita yang kemudian di analisis secara bivariat dan multivariat. Berdasarkan analisis bivariat didapatkan pendidikan ibu $(p=0,022)$, pekerjaan ibu $(p=0,000)$, pendapatan keluarga $(p=0,012)$, jumlah anak $(p=0,008)$ dan pola asuh ibu $(p=0,000)$. Sementara dari analisis multivariat didapatkan pendidikan ibu ( $p=0,004$; OR=2,594; $C \mid 95 \%=1,356-4,963)$, pekerjaan ibu ( $p=0,000 ; O R=74,769 ; C l 95 \%=24,141$ $231,577)$, pendapatan keluarga $(p=0,013$; $O R=3,058 ; C I 95 \%=1,246-7,4)$ dan pola asuh ibu $(p=0,000 ; O R=15,862$; $\mathrm{Cl} 95 \%=5,973-42,128)$. Analisis bivariat menunjukan bahwa terdapat hubungan antara pendidikan ibu, pekerjaan ibu, pendapatan keluarga, jumlah anak dan pola asuh ibu dengan status gizi anak balita. Berdasarkan hasil analisis multivariat faktor pekerjaan ibu merupakan faktor yang paling berhubungan dengan status gizi anak balita.

Kata kunci: status gizi, anak balita, faktor sosial ekonomi

\section{Abstract}

Nutritional status of children under five years has affected by a political and socio-economic condition factors, among others, maternal education, maternal occupation, number of children, maternal knowledge and parenting also parents' economic conditions as a whole. This research is conduct to determine whether there is a relationship between the socio-economic conditions of families on the nutritional status of children under five. This research is a analytic survey using a cross sectional study design with the number of samples are 227 people consisting of children under five and the mothers in the working areas Puskesmas Nanggalo Padang. Data were collected through questionnaires which is completed by mothers whose later been analyzed in bivariate and multivariateBased on bivariate analysis we can get the maternal education $(p=0.022)$, maternal occupation $(p=0.000)$, household income $(p=0.012)$, number of children $(p=0.008)$ and maternal parenting $(p=0.000)$. While the multivariate analysis obtained from the maternal education ( $p=0.004 ; O R=2.594 ;$ Cl95\% $=1.356$ to 4.963), maternal occupation ( $p=$ 0.000; $O R=74.769 ; C 195 \%=24.141$ to 231.577), household income $(p=0.013 ; O R=3.058 ; C 195 \%=1.246$ to 7.4$)$ and maternal parenting $(p=0.000 ; O R=15.862 ; C 195 \%=5.973$ to 42.128$)$. Bivariate analysis showed that there is a relationship between maternal education, maternal occupation, family income, number of children and parenting mothers with a nutritional status of children under five. Based on the results of the multivariate analysis, maternal occupation is the most associated factor with nutritional status of children under five.

Keywords: Nutritional Status, Children Under Five, Socio-economic Factor

Affiliasi penulis : 1. Pendidikan Dokter FK UNAND (Fakultas Kedokteran Universitas Andalas Padang), 2. Bagian Ilmu Gizi FK UNAND, 3. Bagian IKM FK UNAND
Korespondensi :Rona Firmana Putri, E-mail:

ronafirmana@ymail.com, Telp: 085365274073 


\section{PENDAHULUAN}

Pada saat ini balita (bawah lima tahun) sebagai generasi penerus bangsa yang diharapkan menjadi sumberdaya manusia yang berkualitas di masa depan memerlukan perhatian khusus. Usia di bawah lima tahun merupakan "usia emas" dalam pembentukan sumberdaya manusia baik dari segi pertumbuhan fisik maupun kecerdasan, dimana hal ini harus didukung oleh status gizi yang baik karena status gizi berperan dalam menentukan sukses tidaknya upaya peningkatan sumberdaya manusia. ${ }^{1}$

WHO pada tahun 2002 menyebutkan penyebab kematian anak balita urutan pertama disebabkan gizi buruk dengan angka 54\%. Berdasarkan data riset kesehatan dasar (Riskesdas) tahun 2010, secara nasional prevalensi balita gizi buruk sebesar $4,9 \%$ dan kekurangan gizi $17,9 \%$. Hal ini menunjukkan bahwa di Indonesia masih terdapat balita dengan gizi buruk dan kekurangan gizi sehingga pembangunan di Indonesia belum sepenuhnya mampu meningkatkan kualitas hidup sumber daya manusia. $^{1-3}$

Prevalensi status gizi anak balita berdasarkan indeks tinggi badan menurut umur (TB/U) di Indonesia yaitu $17,8 \%$ sangat pendek dan di Provinsi Sumatera Barat 16,35\% juga sangat pendek. Sedangkan untuk prevalensi status gizi berdasarkan indeks berat badan menurut tinggi badan (BB/TB) persentase di Indonesia yaitu 6,7\% dan di Provinsi Sumatera Barat $4,1 \%$ sangat kurus. ${ }^{4}$

Status gizi pada masyarakat dipengaruhi oleh banyak faktor. Kondisi sosial ekonomi merupakan salah satu faktor penting yang mempengaruhi status gizi. Bila kondisi sosial ekonomi baik maka status gizi diharapkan semakin baik. Status gizi anak balita akan berkaitan erat dengan kondisi sosial ekonomi keluarga (orang tua), antara lain pendidikan orang tua, pekerjaan orang tua, jumlah anak orang tua, pengetahuan dan pola asuh ibu serta kondisi ekonomi orang tua secara keseluruhan. ${ }^{5}$

Berdasarkan Data Prevalensi Status Gizi Dinas Kesehatan Kota Padang tahun 2012, kecamatan Nanggalo termasuk ke dalam empat besar wilayah yang prevalensi status gizinya berada di Bawah Garis Merah (BGM) dan terdapat lebih dari
$15 \%$ kasus gizi kurang dan gizi buruk yang ditimbang berdasarkan BB/U. Data Status Gizi Puskesmas Nanggalo tahun 2012 menunjukkan dari 1070 anak balita yang ditimbang berdasarkan BB/U diketahui $1 \%$ gizi sangat kurang, 5\% gizi kurang, $2 \%$ gizi lebih, dan berdasarkan TB/U diketahui $5 \%$ sangat pendek, $8 \%$ pendek, serta berdasarkan BB/TB diketahui $3 \%$ kurus, $8 \%$ gemuk. Data tersebut juga menunjukkan bahwa terdapat $33 \%$ anak balita yang berada pada garis kemiskinan. $^{6,7}$

Penelitian ini dilakukan dengan tujuan untuk mengetahui hubungan kondisi sosial ekonomi keluarga terhadap status gizi anak balita di wilayah kerja Puskesmas Nanggalo.

\section{METODE}

Penelitian ini dilakukan di wilayah kerja Puskesmas Nanggalo Padang dari bulan Januari sampai April 2014. Sampel adalah kelompok anak balita dan kelompok ibu balita (responden yang mengisi kuesioner) yang memenuhi kriteria inklusi yaitu anak balita (1-5 tahun) dan responden bersedia mengisi kuesioner serta tidak memenuhi kriteria eksklusi yaitu anak balita yang sakit atau cacat, responden yang tidak kooperatif dan tidak tahu umur anak balitanya dengan menggunakan teknik simple random sampling. Penelitian ini bersifat analitik dengan desain cross-sectional study. Pengolahan data dilakukan dengan uji chi-square untuk mengetahui hubungan antara variabel dependen dengan variabel independen dan regresi logistik untuk mengetahui variabel independen yang paling berhubungan dengan variabel dependen menggunakan sistem komputerisasi. Variabel dependen adalah status gizi anak balita dan variabel independen adalah tingkat pendidikan ibu, tingkat pengetahuan ibu, jenis pekerjaan ibu, pendapatan keluarga, jumlah anak dan pola asuh ibu.

\section{HASIL}

Berdasarkan hasil penelitian tentang faktorfaktor yang berhubungan dengan status gizi anak balita di wilayah kerja puskesmas Nanggalo Padang didapatkan karakteristik umum subyek penelitian yang ditunjukkan pada tabel dibawah ini: 
Tabel 1. Karakteristik Umum Subjek Penelitian

\begin{tabular}{lcc}
\hline \multicolumn{1}{c}{ Karakteristik } & $\mathrm{f}$ & $\%$ \\
\hline Jenis kelamin & 107 & 47,1 \\
Laki-laki & 120 & 52,9 \\
perempuan & & \\
Usia (bulan) & 86 & 37,9 \\
$12-24$ & 141 & 62,1 \\
$25-60$ & & \\
Berat badan $(\mathrm{kg})$ & 30 & 13,2 \\
$<10$ & 174 & 76,6 \\
$10-15$ & 23 & 10,2 \\
$15-20$ &
\end{tabular}

Pada tabel 1 dapat dilihat bahwa subyek penelitian sebagian besar berjenis kelamin perempuan yaitu sebesar $52,9 \%$, usia $25-60$ bulan sebesar $62,1 \%$ dan berat badan $10-15 \mathrm{~kg}$ sebesar $76,6 \%$.

Tabel 2. Analisis Bivariat

\begin{tabular}{|c|c|c|c|c|c|c|}
\hline \multirow{3}{*}{$\begin{array}{l}\text { Faktor yang } \\
\text { berhubungan }\end{array}$} & \multicolumn{5}{|c|}{ Status gizi } & \multirow{3}{*}{$\mathrm{p}$} \\
\hline & \multicolumn{2}{|c|}{ Kurang } & \multicolumn{2}{|c|}{ Baik } & \multirow{2}{*}{$\begin{array}{c}\text { Total } \\
f\end{array}$} & \\
\hline & $f$ & $\%$ & $f$ & $\%$ & & \\
\hline \\
\hline \multicolumn{7}{|l|}{ pendidikan } \\
\hline \multicolumn{7}{|l|}{ ibu } \\
\hline Rendah & 41 & 47,7 & 45 & 52,3 & 86 & \\
\hline Sedang & 35 & 28,9 & 86 & 71,1 & 121 & 0,022 \\
\hline Tinggi & 7 & 35 & 13 & 65 & 20 & \\
\hline \multicolumn{7}{|l|}{ Tingkat } \\
\hline \multicolumn{7}{|l|}{ pengetahuan } \\
\hline \multicolumn{7}{|l|}{ ibu } \\
\hline Rendah & 59 & 100 & 0 & 0 & 59 & \\
\hline Tinggi & 24 & 14,3 & 144 & 85,7 & 168 & - \\
\hline \multicolumn{7}{|l|}{ Jenis } \\
\hline \multicolumn{7}{|l|}{ pekerjaan ibu } \\
\hline Pekerja & 54 & 76,1 & 17 & 23,9 & 71 & \\
\hline Tidak & & & & & & 0,000 \\
\hline bekerja & 29 & 18,6 & 127 & 81,4 & 156 & \\
\hline \multicolumn{7}{|l|}{ Pendapatan } \\
\hline \multicolumn{7}{|l|}{ keluarga } \\
\hline Rendah & 59 & 43,1 & 78 & 56,9 & 137 & \\
\hline Tinggi & 24 & 26,7 & 66 & 73,3 & 90 & 0,012 \\
\hline \multicolumn{7}{|l|}{ Jumlah anak } \\
\hline$>2$ orang & 30 & 50,8 & 29 & 49,2 & 59 & \\
\hline$\leq 2$ orang & 53 & 31,5 & 115 & 68,5 & 168 & 0,008 \\
\hline \multicolumn{7}{|l|}{ Pola asuh } \\
\hline \multicolumn{7}{|l|}{ ibu } \\
\hline Tidak baik & 45 & 60 & 30 & 40 & 75 & \\
\hline Baik & 38 & 25 & 114 & 75 & 152 & 0,000 \\
\hline
\end{tabular}

Berdasarkan hasil uji statistik pada tabel 2 . didapatkan nilai $\mathrm{p}<0,05$ pada faktor tingkat pendidikan ibu $(p=0,022)$, jenis pekerjaan ibu $(p=0,000)$, pendapatan keluarga $(p=0,012)$, jumlah anak $(p=0,008)$ dan pola asuh ibu $(p=0,000)$ yang menunjukkan bahwa terdapat hubungan yang bermakna antara tingkat pendidikan ibu, jenis pekerjaan ibu, pendapatan keluarga, jumlah anak dan pola asuh ibu dengan status gizi anak balita. Sedangkan pada faktor tingkat pengetahuan ibu tidak dapat dinilai hubungannya karena tidak dapat dilakukan uji statistik.

Tabel 3. Hasil Pemodelan Awal Faktor-faktor yang Berhubungan dengan Status Gizi Anak Balita

\begin{tabular}{lllll}
\hline Variabel & B & p value & $\begin{array}{l}\text { Odds } \\
\text { Ratio/OR }\end{array}$ & Cl 95\% \\
\hline $\begin{array}{l}\text { Tingkat } \\
\begin{array}{l}\text { Pendidikan Ibu } \\
\text { Jenis Pekerjaan }\end{array}\end{array}$ & 0,949 & $0,004^{*}$ & 2,584 & $1,348-4,952$ \\
Ibu & 4,307 & $0,000^{*}$ & 74,205 & $\begin{array}{l}23,858- \\
230,801\end{array}$ \\
$\begin{array}{l}\text { Pendapatan } \\
\text { Keluarga }\end{array}$ & 1,1 & $0,019^{*}$ & 3,003 & $1,202-7,503$ \\
$\begin{array}{l}\text { Jumlah Anak } \\
\text { Pola Asuh Ibu }\end{array}$ & 0,068 & 0,883 & 1,071 & $0,430-2,663$ \\
& 2,761 & $0,000^{*}$ & 15,814 & $5,951-42,029$ \\
\hline
\end{tabular}

Berdasarkan uji statistik pada tabel 3. dikeluarkan tahap demi tahap faktor yang berhubungan dengan status gizi yang memiliki nilai $p<0,05$ dengan uji regresi logistik menggunakan metode Backward.

Tabel 4. Hasil Pemodelan Akhir Faktor-faktor yang Berhubungan dengan Status Gizi Anak Balita

\begin{tabular}{lccll}
\hline Variabel & $\mathrm{B}$ & $\mathrm{p}$ value & $\begin{array}{l}\text { Odds } \\
\text { Ratio/OR }\end{array}$ & $\mathrm{Cl} 95 \%$ \\
\hline $\begin{array}{l}\text { Tingkat } \\
\text { Pendidikan } \\
\text { Ibu }\end{array}$ & 0,953 & 0,004 & 2,594 & $1,356-4,963$ \\
$\begin{array}{l}\text { Jenis } \\
\text { Pekerjaan Ibu }\end{array}$ & 4,314 & 0,000 & 74,769 & $24,141-231,577$ \\
$\begin{array}{l}\text { Pendapatan } \\
\text { Keluarga }\end{array}$ & 1,118 & 0,013 & 3,058 & $1,264-7,4$ \\
\begin{tabular}{l} 
Pola Asuh lbu \\
\hline
\end{tabular} & 2,764 & 0,000 & 15,862 & $5,973-42,128$ \\
\hline
\end{tabular}

Berdasarkan uji statistik pada tabel 4. didapatkan bahwa faktor jenis pekerjaan ibu merupakan faktor yang paling dominan berhubungan dengan status gizi anak balita. 


\section{PEMBAHASAN}

Hasil penelitian ini menunjukan masih ditemukan anak balita yang berstatus gizi kurang yaitu sebesar 36,6\%. Penelitian yang dilakukan oleh Supadi di Puskesmas Wonosalam II Kabupaten Demak mendapatkan hasil yang tidak jauh berbeda yaitu sebesar 39,2\% anak balita di daerah tersebut mengalami status gizi kurang. Apabila kedua penelitian dibandingkan, terlihat bahwa persentase kejadian status gizi kurang pada penelitian Supadi masih lebih tinggi. Hal ini disebabkan karena pada penelitian tersebut didapatkan sebagian besar ibu memiliki tingkat pendidikan yang rendah. Pendidikan yang rendah mempengaruhi tingkat pemahaman terhadap pengasuhan anak termasuk dalam hal perawatan, pemberian makanan dan bimbingan pada anak yang akan berdampak pada kesehatan dan gizi yang semakin menurun., 8

Berdasarkan data Riset Kesehatan Dasar Tahun 2010 secara nasional prevalensi gizi kurang adalah 17,9\%. Jika dibandingkan dengan data tersebut maka angka kejadian gizi kurang di wilayah kerja Puskesmas Nanggalo Padang Tahun 2014 masih terlihat lebih tinggi. Perbedaan prevalensi ini terjadi karena adanya perbedaan pengambilan sampel, dimana pada penelitian Riskesdas sampel diambil di daerah rural dan urban. Sedangkan pada penelitian ini sampel diambil pada daerah rural. Hal ini dijelaskan dalam penelitian yang dilakukan oleh Almarita, bahwa gizi kurang lebih banyak pada daerah rural jika dibandingkan dengan daerah urban.,9

Penelitian yang dilakukan oleh Masithah di Desa Mulya Harja Bogor mendapatkan anak balita dengan status gizi kurang sebesar 16,9\%. Persentase hasil tersebut jauh lebih sedikit dibandingkan dengan penelitian ini. Hal ini disebabkan karena sebagian besar ibu balita di Desa Mulya Harja aktif mengunjungi posyandu dan menghadiri berbagai penyuluhan yang diadakan mengenai ilmu gizi. Sementara pada penelitian ini sesuai yang ditemukan di lapangan, sebagian besar ibu balitanya tidak aktif ke posyandu ataupun mengikuti penyuluhan. Menurut Handayani, penting bagi ibu untuk aktif berkunjung ke posyandu untuk memantau kesehatan dan gizi anaknya, sehingga apabila terjadi masalah seperti gizi kurang maka ibu dapat melakukan pencegahan agar keadaan tersebut tidak semakin buruk. ${ }^{1,11}$

Berdasarkan hasil penelitian ini balita dengan status gizi kurang lebih banyak berasal dari kelompok ibu yang berpendidikan rendah yaitu 47,7\% dibandingkan dengan kelompok ibu yang berpendidikan tinggi yaitu $35 \%$. Hasil penelitian ini sejalan dengan penelitian Ihsan di Desa Teluk Rumbia yang menjabarkan dari 32 balita dengan status gizi kurang, sebanyak 31 orang $(31,6 \%)$ berasal dari kelompok ibu dengan pendidikan rendah dan 1 orang $(12,5 \%)$ berasal dari kelompok ibu dengan pendidikan tinggi. Hasil penelitian didapatkan seperti yang dijabarkan tersebut disebabkan oleh kurangnya pengetahuan ibu mengenai gizi balita. ${ }^{12}$

Berdasarkan analisis bivariat terdapat hubungan yang bermakna antara pendidikan ibu dengan status gizi balita. Hasil ini didukung dengan hasil analisis multivariat yang menunjukan bahwa pendidikan ibu memang merupakan faktor yang berhubungan dengan status gizi balita. Hasil ini sejalan dengan penelitian sebelumnya yang dilakukan oleh Yoseph yang menunjukan bahwa terdapat hubungan yang signifikan antara tingkat pendidikan ibu dengan status gizi balita. Menurut Gusti, balita yang memiliki ibu yang berpendidikan rendah memiliki risiko untuk mengalami status gizi kurang dibandingkan dengan ibu yang berpendidikan tinggi. Namun penelitian yang dilakukan oleh Masithah memiliki hasil yang berbeda yakni, tidak terdapat hubungan yang bermakna antara tingkat pendidikan dengan status gizi balita. Perbedaan hasil ini terjadi karena adanya perbedaan dalam metode dan uji hipotesis yang digunakan. 2,10,11

Berdasarkan literatur, semakin tinggi tingkat pendidikan seseorang maka semakin mudah diberikan pengertian mengenai suatu informasi dan semakin mudah untuk mengimplementasikan pengetahuannya dalam perilaku khususnya dalam hal kesehatan dan gizi. Dengan demikian, pendidikan ibu yang relatif rendah juga akan berkaitan dengan sikap dan tindakan ibu dalam menangani masalah kurang gizi pada anak balitanya. ${ }^{9}$

Hasil penelitian menunjukan bahwa balita dengan status gizi kurang lebih banyak berasal dari 
kelompok ibu yang berpengetahuan rendah. Hal ini disebabkan karena cukup banyak ibu yang berpendidikan rendah pada penelitian ini. Hal ini sesuai dengan teori, bahwa tingkat pendidikan turut menentukan mudah tidaknya seseorang menyerap dan memahami pengetahuan yang mereka peroleh, semakin tinggi pendidikan seseorang maka semakin baik pula pengetahuannya. ${ }^{12}$

Penelitian yang dilakukan oleh Panambunan dan Sjane juga mendapatkan lebih banyak ibu dengan pengetahuan yang rendah memiliki balita dengan status gizi kurang dibandingkan dengan status gizi baik. Namun berbeda dengan penelitian yang dilakukan oleh Yoseph yang menunjukan bahwa balita dengan status gizi kurang lebih banyak berasal dari kelompok ibu yang berpengetahuan tinggi dibandingkan dengan kelompok ibu yang berpengetahuan rendah. $\mathrm{Hal}$ ini dikarenakan ibu kurang menerapkan pengetahuan yang ia miliki mengenai kebutuhan gizi yang harus dipenuhi untuk anak balitanya. Berdasarkan penelitian yang dilakukan oleh Indra, mendapatkan salah satu sebab masalah gizi kurang yaitu kurangnya pengetahuan tentang gizi atau kurang menerapkan informasi tersebut dalam kehidupan sehari-hari. ${ }^{10,13}$

Analisis hubungan antara pengetahuan ibu dengan status gizi balita tidak bisa dilakukan karena terdapat cell yang kosong sehingga hasil ini tidak bisa dibandingkan dengan penelitian serupa yang dilakukan oleh Rahmawati dkk yang mendapatkan hasil bahwa terdapat hubungan yang signifikan antara pengetahuan ibu dengan status gizi balita. Menurut teori, tingkat pengetahuan ibu memang sangat mempengaruhi status gizi balita karena kebutuhan dan kecukupan gizi anak balita tergantung dari pengetahuan ibu mengenai jenis makanan yang diberikan oleh ibu. ${ }^{11,14}$

Hasil penelitian ini mendapatkan balita yang mengalami status gizi kurang lebih banyak berasal dari keluarga yang ibunya bekerja dengan analisis bivariat terdapat hubungan yang bermakna antara pekerjaan ibu dengan status gizi balita. Hasil bivariat ini diperkuat dengan hasil analisis multivariat yang menunjukan bahwa pekerjaan ibu merupakan faktor yang paling berhubungan dengan status gizi balita.
Selain itu hasil penelitian ini tidak jauh berbeda dengan hasil penelitian Miko yang mendapatkan proporsi status gizi kurang pada anak umur 6-60 bulan mempunyai ibu yang bekerja lebih banyak $(22,4 \%)$ dibandingkan dengan ibu yang tidak bekerja (19,9\%) di Kecamatan Bojongasih Kabupaten Tasikmalaya dengan kesimpulan terdapat hubungan pekerjaan dengan status gizi balita. ${ }^{15}$

Menurut kepustakaan, ibu yang tidak bekerja dalam keluarga dapat mempengaruhi asupan gizi balita karena ibu berperan sebagai pengasuh dan pengatur konsumsi makanan anggota keluarga. Ibu yang bekerja tidak memiliki waktu yang cukup untuk mengasuh dan merawat anaknya sehingga anaknya dapat menderita gizi kurang. ${ }^{1}$

Penelitian oleh Ihsan mendapatkan kejadian status gizi kurang terbanyak pada anak balita dengan ibu yang tidak bekerja yaitu 30,2\% sedangkan gizi baik tertinggi pada anak balita dengan ibu yang bekerja yaitu $70 \%$. Hal ini dihubungkan dengan pendapatan keluarga yang rendah. Menurut Supariasa kehidupan ekonomi keluarga akan lebih baik pada keluarga dengan ibu bekerja dibandingkan dengan keluarga yang hanya menggantungkan ekonomi pada kepala keluarga atau ayah. Kehidupan ekonomi keluarga yang lebih baik akan memungkinkan keluarga mampu memberikan perhatian yang layak bagi asupan gizi balita. ${ }^{5,12}$

Hasil penelitian mendapatkan dari 227 ibu balita di wilayah kerja Puskesmas Nanggalo Padang tahun 2014 persentase pendapatan keluarganya masih rendah yaitu sebesar 60,4\% dan persentase balita yang mengalami status gizi kurang lebih banyak berasal dari keluarga yang pendapatannya rendah yaitu $43,1 \%$ sedangkan pada keluarga yang berpendapatan tinggi hanya terdapat $26,7 \%$ balita dengan status gizi kurang. Hal ini disebabkan karena pada penelitian ini rata-rata kepala keluarga hanya bekerja sebagai petani dan ibu hanya sebagai ibu rumah tangga. Selain itu dalam satu keluarga sebagian besar memiliki anak lebih dari 2 orang dengan jarak antara satu anak dengan anak yang lainnya tidak terlalu jauh. Hasil ini sejalan dengan penelitian yang dilakukan oleh Sander yang mendapatkan bahwa anak balita dengan status gizi 
yang kurang lebih banyak berasal dari keluarga yang berpendapatan rendah yaitu $53,1 \%$ dan pada keluarga yang berpendapatan tinggi sebesar $22 \%{ }^{16}$

Hasil analisis bivariat menunjukan terdapat hubungan pendapatan keluarga dengan status gizi balita. Diikuti dengan hasil analisis multivariat yang dilakukan menunjukan bahwa pendapatan keluarga merupakan salah satu faktor yang berhubungan dengan status gizi balita. Hasil ini selaras dengan penelitian yang dilakukan oleh Woge dan Yoseph yang mendapatkan bahwa terdapat hubungan yang bermakna antara pendapatan keluarga dengan status gizi balita di Kecamatan Kelimutu Kabupaten Ende Flores Provinsi Nusa Tenggara Timur. Berbeda dengan Suhendri yang mendapatkan hasil bahwa tidak terdapat hubungan yang bermakna antara pendapatan keluarga dengan status gizi balita di Puskesmas Sepatan Kecamatan Sepatan Kabupaten Tangerang. Perbedaan hasil ini disebabkan karena adanya perbedaan metode dan uji hipotesis yang digunakan. ${ }^{10,17}$

Menurut teori, jika suatu keluarga memiliki pendapatan yang besar serta cukup untuk memenuhi kebutuhan gizi anggota keluarga maka pemenuhan kebutuhan gizi pada balita dapat terjamin. ${ }^{1}$ Sementara Pendapatan yang rendah menyebabkan daya beli rendah sehingga tidak mampu membeli pangan dalam jumlah yang diperlukan dan pada akhirnya berakibat buruk terhadap status gizi anak balitanya. ${ }^{15}$

Hasil penelitian ini menunjukan bahwa persentase ibu dengan jumlah anak $>2$ orang lebih banyak menderita status gizi kurang yaitu 50,8\% dibandingkan dengan ibu yang jumlah ankanya $\leq 2$ orang yaitu $31,5 \%$. Hasil bivariat menunjukan terdapat hubungan jumlah anak dengan status gizi. Hasil ini sejalan dengan penelitian yang dilakukan oleh Ihsan di Desa Teluk Rumbia Kecamatan Singkil Kabupaten Aceh Singkil, pada penelitiannya didapatkan bahwa kejadian status gizi kurang tertinggi pada jumlah anak $>2$ orang yaitu 32,9\% dengan hasil analisis terdapat hubungan jumlah anak dengan status gizi balita. Menurut kepustakaan, jumlah anak yang banyak akan berpengaruh terhadap tingkat konsumsi makanan, yaitu jumlah dan distribusi makanan dalam rumah tangga. Dengan jumlah anak yang banyak diikuti dengan distribusi makanan yang tidak merata akan menyebabkan anak balita dalam keluarga tersebut menderita kurang gizi. ${ }^{12,17}$

Pada penelitian yang dilakukan oleh Dewati menunjukan hal yang berbeda yakni, tidak terdapat hubungan antara jumlah anak dengan status gizi balita. Perbedaan hasil ini disebabkan oleh berbedanya karakteristik jarak umur anak. Pada penelitian ini rata-rata didapatkan jumlah anak yang lebih dari 2 orang dengan jarak umur anak yang dekat. Sementara pada penelitian Dewati didapatkan sebagian besar jumlah anak juga lebih dari 2 orang namun jarak umur anak yang satu dengan anak yang lainnya rata-rata 4 tahun keatas. ${ }^{18}$

Jumlah anak yang banyak pada keluarga meskipun keadaan ekonominya cukup akan mengakibatkan berkurangnya perhatian dan kasih sayang orang tua yang di terima anaknya, terutama jika jarak anak yang terlalu dekat. Hal ini dapat berakibat turunnya nafsu makan anak sehingga pemenuhan kebutuhan primer anak seperti konsumsi makanannya akan terganggu dan hal tersebut akan berdampak terhadap status gizi anaknya. ${ }^{13-15}$

Hasil penelitian menunjukan bahwa persentase anak balita yang mengalami status gizi kurang lebih banyak terjadi pada ibu dengan pola asuh yang tidak baik yaitu $60 \%$ dan hasil analisis bivariat menunjukan terdapat hubungan antara pola asuh dengan status gizi balita. Hasil ini sejalan dengan penelitian yang dilakukan Aswin bahwa terdapat $33,8 \%$ balita yang mengalami status gizi kurang akibat pola asuh yang tidak baik sedangkan pada pola asuh ibu yang baik hanya terdapat 19,2\% balita yang mengalami status gizi kurang dengan hasil uji statistik menunjukan bahwa terdapat hubungan yang bermakna antara pola asuh ibu dengan status gizi. ${ }^{19}$

Penelitian oleh Miko juga menunjukan terdapat hubungan antara pola asuh ibu dengan status gizi balita dengan persentase anak balita yang mengalami status gizi kurang lebih banyak pada ibu yang pola asuhnya tidak baik yaitu $73 \%$ sedangkan pada ibu dengan pola asuh yang baik $42,2 \%$. Diikuti dengan penelitian yang dilakukan oleh Aswin yang mendapatkan bahwa terdapat hubungan antara pola asuh ibu dengan status gizi balita. Hasil analisis 
multivariat pada penelitian ini juga menunjukan bahwa pola asuh ibu merupakan faktor yang berhubungan dengan status gizi balita. ${ }^{15,19}$

Sampai saat ini, peneliti masih belum menemukan perbedaan dari hasil penelitian ini. Ratarata penelitian lain mengenai hubungan pola asuh ibu terhadap status gizi balita selalu memiliki hasil bahwa terdapat hubungan yang signifikan antara pola asuh ibu dengan status gizi balita. Hal ini sesuai dengan teori yang menyatakan bahwa pola asuh sangat mempengaruhi status gizi seperti memberikan perhatian yang penuh serta kasih sayang pada anak, memberi waktu yang cukup untuk memperhatikan asupan gizinya sehingga status gizi anak menjadi lebih baik. Selain itu berdasarkan penelitian Hamal anak-anak yang selalu mendapat tanggapan, respon dan pujian dari ibunya menunjukan keadaan gizi yang lebih baik. ${ }^{2,20}$

\section{KESIMPULAN}

Terdapat hubungan yang bermakna antara pendidikan ibu, pekerjaan ibu, pendapatan keluarga, jumlah anak dan pola asuh ibu dengan status gizi anak balita. Pekerjaan ibu merupakan faktor yang paling dominan berhubungan dengan status gizi. Faktor pengetahuan ibu tidak dapat dilakukan uji statistik sehingga tidak didapatkan hubungan.

\section{DAFTAR PUSTAKA}

1. Handayani IS. Hubungan Antara Sosial Ekonomi Keluarga dengan Status Gizi Balita Indonesia [serial online]. 2008 (diunduh 24 Agustus 2013). Tersedia dari: URL: HYPERLINK http://repository.ipb.ac.id/bitstream/handle/1234567 89/50164/G08ish2.

2. Gusti AKM. Hubungan Perilaku lbu dalam Pemberian Gizi Seimbang dengan Status Gizi pada Balita di Posyandu Kelurahan Depok Kecamatan Pancoran Mas Kota Depok (Skripsi). Jakarta: Fakultas IImu Kesehatan, Universitas Pembangunan Nasional Veteran. (Published); 2010.

3. Riset Kesehatan Dasar. Laporan Riset Kesehatan Dasar 2010. [serial online]. 2010 (diunduh 1 Maret 2014). Tersedia dari: URL: HYPERLINK http://litbang.depkes.go.id/sites/download/buku lap oran/lapnas riskesdas2010/Laporan riskesdas 20 10.pdf.

4. Kementrian Kesehatan Republik Indonesia. Profil Kesehatan Indonesia 2010. Jakarta: Departemen Kesehatan Republik Indonesia; 2010.

5. Supariasa IDN. Penilaian Status Gizi. Jakarta: EGC; 2002.

6. Dinas Kesehatan Kota Padang. Laporan Tahunan Data Prevalensi Status Gizi tahun 2012. Padang: Dinas Kesehatan; 2012.

7. Puskesmas Nanggalo Kota Padang. Laporan Tahunan Rekapitulasi Hasil Penimbangan Massal tahun 2012. Padang: Puskesmas Nanggalo; 2012.

8. Supadi J. Analisis Faktor-faktor Pola Asuh Gizi Ibu dengan Status Gizi Anak Balita di Puskesmas Wonosalam II Kabupaten Demak. Jurnal Gizi Klinik Indonesia. 2002; 2(7):70-6.

9. Atmarita TS. Analisis Situasi Gizi dan Kesehatan Masyarakat. Jakarta: Rineka Cipta; 2004.

10. Woge A, Yoseph R. Faktor-faktor yang berhubungan dengan Status Gizi Anak Balita di Kecamatan Kelimutu Kabupaten Ende Flores Provinsi Nusa Tenggara Timur. Jurnal Gizi Klinik Indonesia. 2007; 1(3): 92-4.

11. Masithah T. Hubungan Pola Asuh lbu dan Kesehatan dengan Status Gizi Balita di Desa Mulya Harja Bogor. Jurnal Gizi dan Pangan. 2005; 34(1): 39-49.

12. Ihsan M. Faktor-faktor yang Berhubungan dengan Status Gizi Anak Balita di Desa Teluk Rumbia Kecamatan Singkil Kabupaten Aceh Singkil. Jurnal Gizi Indonesia. 2012; 22(3): 44-54.

13. Panambunan W, Sjane $H$. Hubungan Tingkat Pengetahuan lbu, Status Pekerjaan lbu dan Pola Makan terhadap Status Gizi Balita di Desa Blimbing Kecamatan Sambirejo Kabupaten Sragen. Jurnal Penelitian Gizi dan Makanan. 2006; 48(11): 69-78

14. Rahmawati I, Sudargo T, Paramastri I. Pengaruh Penyuluhan dengan Media Audio Visual Terhadap Peningkatan Pengetahuan Sikap dan Perilaku Ibu Balita Gizi Kurang dan Buruk di Kabupaten Kotowaringin Barat Provinsi Kalimantan Tengah. Jurnal Gizi Klinik Indonesia. 2007; 4(2): 69-77.

15. Miko H. Faktor-faktor yang Berhubungan dengan Status Gizi Anak Umur 6-60 bulan di Kecamatan 
Bojongasih Kabupaten Tasikmalaya. Jurnal Gizi Indonesia. 2003; 1(1): 7-15.

16. Sander S. Hubungan Faktor Sosial Ekonomi, Higiene Sanitasi Lingkungan, Tingkat Konsumsi dan Infeksi dengan Status Gizi Anak Balita di Kabupaten Semarang. Jurnal Penelitian Gizi dan Makanan. 2003; 89(17): 225-33.

17. Suhendri $U$. Faktor-faktor yang Berhubungan dengan Status Gizi Anak Balita di Puskesmas Sepatan Kecamatan Sepatan Kabupaten Tangerang. (Skripsi), Jakarta: Fakultas Kedokteran, Universitas Syarif Hidayatullah; (Published).2009.
18. Dewati NS. Faktor-faktor yang Mempengaruhi Status Gizi Balita Di Wilayah Kerja Puskesmas Sewon I Bantul. Jurnal Kesehatan Masyarakat. 2008; 6(3): 128-40.

19. Aswin RK. Pengaruh Karakteristik Keluarga dan Pola Asuh Ibu pada BalitaGizi Kurang dan Gizi Buruk di Kabupaten Lombok Barat. Jurnal Kesehatan Prima. 2008; 24(3): 333-42.

20. Hamal DK, Hubungan Pendidikan dan Pekerjaan Orangtua Serta Pola Asuh dengan Status Gizi Balita di Kota dan Kabupaten Tangerang Banten. Jurnal Penelitian Gizi dan Makanan. 2011; 26(2):10-9. 